\title{
MODELAGEM NUMÉRICA DE ELEMENTOS ESTRUTURAIS DE CONCRETO DE AGREGADO RECICLADO PROVENIENTE DE RESÍDUOS DE CONSTRUÇÃO E DEMOLIÇÃO A PARTIR DO MÉTODO DE REDE NEURAL ARTIFICIAL (RNA)
}

\author{
Priscila Araujo de Souza ${ }^{1}$; Koji de Jesus Nagahama ${ }^{2}$ \\ 1. Bolsista PIBIC/CNPq, Graduando em Engenharia Civil, Universidade Estadual de Feira de Santana, e-mail: \\ pri_aaraujo@hotmail.com \\ 2. Orientador, Departamento de Tecnologia, Universidade Estadual de Feira de Santana, e-mail: koji@ uefs.br
}

PALAVRAS-CHAVE: resíduo de construção e demolição; redes neurais artificiais; concreto reciclado; agregado reciclado

\section{INTRODUÇÃO}

A indústria da construção civil é uma das principais consumidoras de recursos naturais e geradoras de resíduos. Com o objetivo de reduzir-se o impacto causado por esse setor, os pesquisadores vêm desenvolvendo novos materiais à base de cimento com incorporação de resíduos provenientes de construção e demolição.

No entanto, os agregados reciclados apresentam uma composição bastante heterogênea, visto que podem ser constituídos por rochas naturais, argamassa, concreto e cerâmica, e existe uma grande dificuldade ao tentar prever o seu comportamento e propriedades físicas e mecânicas. As redes neurais (RNA), graças à sua capacidade de reconhecer padrões, podem ser aplicadas para a predição dessas propriedades, com isso a necessidade de ensaios laboratoriais é reduzida e consequentemente o tempo e o custo.

\section{METODOLOGIA}

Para a realização da pesquisa, inicialmente foi necessário realizar o estudo das propriedades físicas e mecânicas do concreto que eram mais relevantes, também dos modelos analíticos existentes e da técnica de inteligência artificial: rede neural artificial. Além de ser esse o momento para se definir o software mais apropriado ao desenvolvido do projeto, que neste caso é o Matlab.

Na fase seguinte ocorre a preparação dos dados, seguida da formatação e da verificação da consistência dos mesmos, para que então os dados possam ser divididos em subconjuntos que servirão para realização de testes e treinamentos. E a mineração de dados, que é aplicação do algoritmo de indução de conhecimento gerando um modelo de conhecimento que está diretamente relacionado com o algoritmo escolhido. Por fim, nessa fase é feita a avaliação do conhecimento inferido, onde é analisada a qualidade do conhecimento extraído.

$\mathrm{Na}$ última etapa, ocorre a divulgação dos modelos propostos e aplicação nos trabalhos experimentais que foram desenvolvidos nos Programas de Pós-Graduação em Engenharia das quatro IES envolvidas no projeto supramencionado que envolve as instituições: UFRGS, UFPA, UNISINOS e UEFS.

\section{RESULTADOS E DISCUSSÃO}

O principal objetivo do projeto era gerar uma equação que pudesse prever de forma confiável as propriedades analisadas e, através disso, avaliar o comportamento físico e mecânico de concretos com agregados provenientes de resíduos de construção e demolição, utilizando para isso um banco de dados já existente de diversas áreas do país com as principais propriedades e a partir do método de Rede Neural Artificial, juntamente com o método de Análise de 
Componentes Principais. No entanto, o objetivo não pôde ser alcançado devido à interrupção da pesquisa, que ocorreu antes da preparação e análise dos dados.

\section{CONSIDERAÇÕES FINAIS}

Não foi possível alcançar o objetivo geral, que era a determinação da equação e a análise do comportamento das propriedades físicas e mecânicas de concretos com agregados contendo RCD, visto que a pesquisa não foi finalizada, logo, nada se pode concluir a respeito.

No entanto, foi possível verificar, através da criação de equações mais simples, o mecanismo e desempenho do sistema de Rede Neural Artificial (RNA) e analisar a precisão da modelagem e o quanto o método empregado é confiável, além de fazer a verificação da influência de cada uma das variáveis de entrada no resultado obtido. O método de RNA sem dúvida é uma ferramenta de grande importância, já que se adapta facilmente a vários tipos de estudos que se deseja realizar, onde, após a sua aprendizagem, ou treinamento, gera um modelo que poderá ser aplicado com alto grau de confiabilidade.

\section{REFERÊNCIAS}

BAZUCO, R. S. Utilização de agregados reciclados de concreto para a produção de novos concretos. Florianópolis, 1999. 100 p. Dissertação (Mestrado) Curso de Pós-graduação em Engenharia Civil da Universidade Federal de Santa Catarina.

BRAGA, A. P., CARVAlHO, A. P. L. F., LUDERMIR, T. B. Redes Neurais artificiais: Teoria e aplicações. Rio de Janeiro: Ed. LTC, 2000.

JI, T., LIN, T., LIN, X., 2006, A concrete mix proportion design algorithm based on artificial neural networks, Cement and Concrete Research, 36(7), p. 1399-1408.

KOVACS, Z. L., 1996, Redes neurais artificiais fundamentos e aplicações. São Paulo: Acadêmica.

LEITE, M. B. Avaliação de propriedades mecânicas de concretos produzidos com agregados reciclados de resíduos de construção e demolição. Porto Alegre, 2001.270p. Tese Doutorado Universidade Federal do Rio Grande do Sul.

OIKONOMOU, N. D. Recycled concrete aggregates. Cement and Concrete Composites. 27 (2005), 315-318.

QUEBAUD, M. R.; ZAHARIEVA, R.; WIRQUIN, E.; BUYLE-BODIN, F. Influência do teor em agregados proveniente da reciclagem de materiais de demolição (agregados reciclados) na permeabilidade do concreto. In: CONGRESSO BRASILEIRO DE CONCRETO, 41., 1999, Salvador. Anais... [CD-ROM]. São Paulo: IBRACON, 1999. Arquivo: 2-1-18, 16p. 